4open 2019, 2, 7

(C) B.L.D.M. Brücher and I.S. Jamall, Published by EDP Sciences 2019

https://doi.org/10.1051/fopen/2019002

\title{
Undervalued ubiquitous proteins
}

\author{
Björn L.D.M. Brücher ${ }^{1,2,3, *}$, Ijaz S. Jamall ${ }^{1,2,4}$ \\ ${ }^{1}$ Theodor-Billroth-Akademie ${ }^{\circledR}$, Germany, USA \\ 2 INCORE, International Consortium of Research Excellence of the Theodor-Billroth-Academy ${ }^{\circledR}$, Germany, USA \\ 3 Department of Surgery, Carl-Thiem-Klinikum, Cottbus, Brandenburg, Germany \\ ${ }^{4}$ Risk-Based Decisions Inc., Sacramento, CA, USA
}

Received 5 March 2018, Accepted 21 January 2019

\begin{abstract}
The role of ubiquitous proteins (UPs) and their corresponding enzymes have been underestimated in carcinogenesis as the focus of much research revolved around measuring mutations and/or other genetic epiphenomena as surrogate markers of cancer and cancer progression. Over the past three decades, the scientific community has come to realize that the concentration on microdissection of cancer cells without accounting for the neighborhood in which these cells reside, i.e., the stroma, fails to reflect the true nature of cancer biology. UPs are fundamental for cellular homeostasis and phylogenetic development as well as for the integrity of the cytoskeleton and for the stability of cells and tissues in regards to intercellular signaling, cell shape and mobility, apoptosis, wound healing, and cell polarity. Corresponding enzymes are used by microorganisms to gain entry into the host by degradation of UPs and play a role to cleave peptide bonds for killing disease-causing life forms along for the creation of the precancerous niche (PCN) during carcinogenesis, cancer invasion, and in metastasis. The language used by such proteins as well as their complementary enzymes with its influence on multiple pathways and the cross-linked extracellular matrix is incompletely understood. The role of UPs in the disruption of signaling homeostasis and resulting interference with crosstalk in carcinogenesis appears sufficiently delineated to warrant a much more refined examination of their qualitative and quantitative contribution to the development of cancer and cancer therapy.
\end{abstract}

Keywords: Autophagy, cancer, carcinogenesis, cell transition, chronic inflammation, collagen, collagenase, crosslinking, cytoplasm, cytoskeleton, decorin, degradation, desmosin, ECM, elastin, elastase, epidermis, epigenetics, epithelium, extracellular matrix, fibroblast, fibromodulin, fibronectin, fibrosis, genomics, inflammation, keratin, keratinase, lysyl oxidase, metaplasia, microRNA, mutation, pathogenesis, polypeptites, precancerous niche, proteins, proteoglycan, proteomics, signaling, vimentin

\section{Introduction}

The role of ubiquitous proteins (UPs) and their corresponding enzymes have been underestimated in carcinogenesis as the focus of much existing research revolves around measuring mutations and/or other genetic epiphenomena as surrogate markers of cancer and cancer progression. Over the past three decades, the scientific community has come to realize that the concentration on microdissection of cancer cells without accounting for the neighborhood of cancer cells (i.e., the stroma) fails to reflect the true nature of cancer biology.

\section{Ubiquitous proteins (UPs)}

Proteins are macromolecules consisting of amino acids connected by peptide bonds. The building blocks of

\footnotetext{
*Corresponding author: b-bruecher@gmx . de
}

proteins and polypeptides contain an acid amino group (CHOO), a basic amine group $\left(\mathrm{NH}_{2}\right)$, a hydrogen atom, a variable side chain, and a central C-atom [1]. Side chains can be nonpolar (e.g., glycine, alanine, valine, leucine, and isoleucine), charged polar (e.g., glutamic acid, aspartic acid, histidine, lysine, and arginine), non-charged polar (e.g., cysteine, methionine, threonine, serine, proline, glutamine, and asparagine), and aromatic (e.g., phenylalanine, tryptophan, and tyrosine). The primary structure describes the sequence of the individual amino acids in polypeptide chains. With this linear 2D primary structure, 3D structural elements develop which are arranged to form the spatial structure of a protein. Additionally, single proteins can assemble to form one functional protein or a protein complex, called a quaternary structure.

For the study of proteins in general, one needs to be careful as false negative or false positive results can occur. Using formalin and paraffin fixation can result for keratin and vimentin assays yields false negative findings [2] which 
may skew the interpretation of data when using immunohistochemical studies to investigate cytoskeletal proteins and their role in carcinogenesis. Alcohol-fixed specimens showed $100 \%$ staining against vimentin while this decreased to $63 \%$ in formalin-fixed tissues [3], a finding that was subsequently reproduced [4].

The concentration on microdissection of cancer cells without accounting for the stroma fails to reflect the true nature of cancer biology [5]. Several approaches were made to differentiate between different stroma-associated tumors [6].

The extracellular matrix (ECM) is much more than just a cell-free space between cells. It is not by accident that Robert Hynes stated that the ECM does not consist out of "...just pretty fibrils" [7]. The ECM is a dynamic repository for growth factors [8] and continuously undergoes deposition, degradation, and modification [9]. The complex network of proteins and filaments of the ECM coregulate cell proliferation, survival, and migration [10]. Various grow factors bind to ECM proteins and additionally a binding of a growth factor to its receptor, such as fibroblast growth factor (FGF) to fibroblast growth factor receptor (FGFR) needs simultaneous chain-binding to heparin sulfate which functions as a cofactor ([11] reviewed in [7]). To measure various proteins and filaments is a challenge as proteins are often "large, cross-linked and covalently bound, heavily glycosylated" $([12,13]$ reviewed in $[14])$.

UPs include keratin, keratinase, collagen, collagenase, elastin, elastase, vimentin, fibronectin, and decorin. The language used by such proteins influences multiple pathways and affects the ECM in ways that are still incompletely understood. A closer look at each of these UPs illustrates what is presently known of their role in cancer.

\section{Keratin}

Detailed information about the chemistry of keratins (KRTs) was published in 1965 [15]. The mechanical properties were reported in 1980 [16] and extensively reviewed [17]. Keratin occurs in vertebrates, birds and reptiles. It is the major component of skin, hair, nails, teeth as well in hooves and horns. Keratin is considered to be nonreactive and mechanically durable. The largest gene family in KRTs was shown to contain up to 54 functional genes [18] which are clustered on chromosomes 12q13.13 and $17 \mathrm{q} 21.2$ with differing expression patterns ([19] reviewed in [20]). The importance of KRTs goes beyond maintaining the integrity of the cytoskeleton and its role in the stability of cells and tissues to intercellular signaling, apoptosis, wound healing, and cell polarity [18]. Although the impact of KRTs in carcinogenesis has not been elucidated, it has been suggested that mitosis can be both regulated and promoted by KRTs [21].

The characteristic of KRTs as being inflexible and hard is based on the cysteine disulfide bridges which create a helical shape and sulfide atoms which bond to each other such that the resulting fibrous matrix is not readily soluble. The number of cysteine bridges contributes to the strength of the bonds in keratin. Sequences of keratin were first reported in 1982 when two different types were identified: Type I and II keratin [22]. Crystal structure analysis confirmed $\alpha$ - and $\beta$-helical conformations [23]. Different KRTs were identified, and in 2006 a consensus nomenclature for mammalian KRTs was proposed and accepted [24]. Twenty cyto-keratins were identified with molecular masses between 40 and $68 \mathrm{kDa}$, abbreviated as KRTs. KRT 1-8 contain eight neutral-basic KRTs while KRT9-20 contain 12 acid keratins. KRTs are dimers composed of neutral-basic and acid KRTs subunits and many dimers come together to form protofilaments, followed by further dimerizing to form protofibrils; protofibrils form tetramers called microfibrils and microfibrils associate into macrofibrils [18]. The distribution pattern of these complexes differs in different epithelial cells, and antibodies against the subtypes KRT1-20 have been developed for use in pathology with the goal to determine the origin of tumor metastases.

The epidermis contains multi-layered keratinizing epithelium (KRT1-9 and KRT2-10), the epithelium of the mouth, pharynx, larynx, esophagus, anal canal, vagina, uretra contain multi-layered non-keratinized squamous epithelium (KRT4-13) or (KRT6A with KRT16 or KRT17) while the epithelium of the respiratory tract consists of basal cells of complex1 epithelial cells (KRT5 with KRT14 or KRT15). Epithelia of all mucosal cells in the stomach and bowel are layered epithelium and luminal glandular cells (KRT7-19 or KRT8 with KRT18 or KRT20). This pattern of distribution shows that keratin is a widespread protein in nature and is also found in the nuclei and cytoplasm of almost all differentiated eukaryote cells [25].

Hepatocyte activator inhibitor type 1 (HAI-1) has been shown to be critical in maintaining normal keratinocyte morphology [26] and KRT19 has been shown to be a putative cancer stem cell (CSC) marker associated with epithelial-mesenchymal transition (EMT) and transforming growth factor beta (TGF- $\beta$ )/Smad signaling [27]. KRT8 was observed to be expressed to a lesser degree in primary tumors while it was positive in lymph node metastasis [28] which implies that the earliest degradation starts within the PCN in primary tumors and not in locations where cancer subsequently spreads.

It was reported some 50 years ago in a study of 115 autopsies and 168 surgically excised specimens of patients with irradiated squamous cell carcinomas of various sites that despite necrosis, extensive and marked keratogenesis were characterized by abundant central masses of hyperkeratotic tissues [29]. Therefore, hyperkeratinization is likely to be an early step as a reaction to keratinase before degradation of the tissue. Radiation-induced keratogenesis was suggested to represent a survival strategy of damaged cancer cells as hyperkeratosis with squamous metaplasia was also observed in chronic inflammation. Periodic biopsies during irradiation of 28 patients with squamous cell carcinoma of the mouth and oropharynx showed that small daily doses of radiation 
resulted in hyperkeratotic tissue of radio-resistant cells next to pockets of destroyed cancer cells [30].

KRTs found in the cytoplasm, cytoskeleton, and epithelial cells are named cytokeratins and are components of intermediate filaments. It is known that cytokeratins are of importance for phylogenetic development as well for the identification of the origin of cells for diagnosing cancerous lesions [31] such as an estimation of apoptosis/necrosis ratio in liver diseases. However, KRTs have a greater tendency for cross-linking and Mallory bodies in chronic liver disorders underlie a chemical memory in terms of the causative factor, alcohol. This phenomenon was shown to be reversible. Furthermore, the degeneration of hepatocytes and the promotion of fibrosis is correlated with the expression of cytokeratin 18 and its caspase-cleaved fragments [32].

\section{Keratinase}

Keratinase, an enzyme that breaks down keratin, is obtained from fungi, bacteria, and actinomycetes for industrial purposes for the preparation of animal nutrients, protein supplements, leather manufacture, textile processing, detergent formulation, feather meal processing for feed and fertilizer, the pharmaceutical and biomedical industries, and waste management (reviewed in $[33,34]$ ), yet no highly sensitive assay is available to detect keratinase.

The hydrolysis of strongly cross-linked keratin can be done by microbial proteolytic keratinases [35]. Since then, many microorganisms such as bacteria as well as dermatophilic fungi have been shown to degrade keratin by keratinolysis [36,37]. Dermatophytes, such as Tryptophan rubrum, secrete keratinases and other enzymes that allow the dermatophyte to burrow deeper into the stratum corneum, and the polysaccharide, Mannan, with a lipophilic toxin can inhibit cell-mediated immunity [38]. It was suggested that membrane potential plays a role in keratin degradation to make the chains available for cleavage by proteinases [39].

The keratinocyte growth factor (KGF), identified in 1989, and shown to exert its effect in a paracrine manner, is limited to epithelial cells [40] and is likely responsible for the remarkable aggressiveness and proliferation of scirrhous gastric cancer cells in a paracrine manner [41]. KGF is released by fibroblasts in wound healing, participates in epidermal homeostasis in regard to epithelial proliferation, differentiation, and migration, and binds to fibroblast growth factor receptor 2 (FGFR2b) [42-44]. The E5 oncoprotein of human papillomavirus type 16 (HPV16 E5) decreases KGFR/FGFR2b [45] resulting in the deregulation of signal transduction [46], and the induction of interferon regulatory factor 1 (IRF-1) stimulating interferin beta (IFN- $\beta$ ) [47]. One regulation of KGFR is by the transcription factor E2F1: knockout of activated aryl hydrocarbon receptor (AhR) led to KGFR downregulation and transfection with siRNA specific for AhR (siAhR) reduced E2F1 in the nucleus [48]. Thereby
AhR-E2F1-KGFR signaling is actively involved in epithelial cell proliferation and early carcinogenesis. However, papilloma viruses are not just important for the development of human cancer but also a problem in veterinary medicine including for canines, felines and bovine species [49].

\section{Collagen}

Collagen is present in all multicellular organisms and is the most abundant protein in vertebrates [50-52]. Extracellular proteins form insoluble fibers with great tensile strength. Collagen is a major stress-bearing component of connective tissue found in bone, teeth, cartilage, tendon, skin, etc. and mammals have at least 33 distinct collagen subunits that form $>20$ different quaternary structures. Nearly $33 \%$ of the residues in collagen have glycine (Gly) as the primary amino acid, and another 15-30\% have Pro (4-hydroxyproline) with a smaller fraction containing 3-hydroxyproline and 5-hydroxylysine. The enzyme converting Pro to 4-hydroxyproline is prolyl hydroxylase which requires ascorbic acid (vitamin $\mathrm{C}$ ) to be activated.

Repeating Gly-X-Y sequences comprise collagen's quaternary structure with Pro typically found in the $\mathrm{X}$-position and hydroxyproline in the Y-position. These three collagen polypeptides are wrapped around each other forming a right-handed triple helix. In every third position, Gly is required for achieving the close-packing of the subunits. By comparison to keratin's crosslinking with disulfide bonds, cross-links in collagen are between Lys (and His) residues because collagen is nearly devoid of Cys.

Lysyl oxidase (LOX), a copper-dependent enzyme, is known to form crosslinks of the ECM by oxidative deamination converting a specific lysine and hydroxylysine residue in collagen to peptide-bound aldehydes which can be irreversibly inhibited by $\beta$-amino-proprio-nitrile $(\beta A P N)$, a copper chelator [53]. The ability of an agent or enzyme to inhibit crosslinks depends on the types of crosslinks that stabilize that particular collagen fiber.

\section{Collagenase}

The role of collagenase, produced by inflammatory cells, and required to degrade collagen has been known for some 40 years and denaturation can result in gelatin formation [54]. Metalloproteinases (MMPs) are associated with breast cancer development and "can be loosely divided into four main groups: the interstitial collagenases, gelatinases, stromelysins, and membrane-type MMPs" [55]. MMP-mediated degradation of type I collagen (C1M), type IV collagen (C4M), and citrullinated vimentin (VICM) appear important for remodelingmediated matrix and have been investigated in 5855 Danish samples in The Prospective Epidemiologic Risk Factor (PERF I) study: C1M and VICM were associated with survival in postmenopausal cancer and $\mathrm{C} 1 \mathrm{M}$ was identified as an independent risk factor for cancer-specific mortality [56]. 
The expression of type IV collagenase is modulated by influenza A/Beijing/353/89 (H3N2) virus at the transcriptional level, is dependent on the epithelial cell line under investigation through matrix MMP-9 (in Vero cells), and on matrix MMP-2 in Madin-Darby canine kidney (MDCK) cells [57]. Interestingly, investigation of matrix MMP-13 in serum and saliva and collagenase-3 in a pre-malignant condition (oral lichen planus) and in cancer (oral squamous cell carcinoma) revealed nearly equal levels, although serum MMP-13 was associated with unstimulated and not stimulated saliva MMP-13 [58].

The enzymes of named UPs seem to play a role in the dissemination of cancer. For example, in breast cancer a switch of the kinase-MMP network was observed: neuregulin (NRG) augmented MMPs expression by extracellular signal-regulated kinase 1 (Erk1, mitogenactivated protein kinase 3, MAPK3)/extracellular signalregulated kinase 2 (Erk2, mitogen-activated protein kinase 1, MAPK1) and increases collagenase 3 expression by controlling the activity of a myotubularin-related protein 5 (SBF1) related transcription factor [59].

\section{Elastin}

Augmented or condensed elastin in breast cancer was first described in 1957 [60] and alterations in collagen and elastin along epithelial and stromal junctions in breast cancer were reported in 1970 [61]. Although Lundmark showed some $70 \%$ elastosis in breast cancer tissue, the real elastin content could not be determined as differences in irradiated and non-irradiated tissue were found along with a shift to higher incidences in patients over $40 \mathrm{yr}$ [62]. Elastin is a fibrous protein in vertebrates and is responsible for shape as it lends compliance to large blood vessels and organs such as lungs, liver, spleen, and skin [63]. Elastin has a composition similar to collagen. It however does not contain hydroxylysine, but instead contains a significant proportion of valine $(15.6 \%)$. Lysine residues can be oxidized by LOX to allysin and each three allysin plus a lysine may be converted into an annular desmosin contributing to the resilience of the whole molecule. The soluble precursor is tropoelastin. Hereditary diseases such as Williams-Beuren syndrome or congenital subvalvular aortic stenosis (SVAS) can be caused by mutations within the elastin gene.

The protein network in elastin consists of cross-linked elastin units and the cross-linking enzyme, LOX, remodels elastin after it has been secreted from cells in soluble form. The amino acid, Lys, is responsible for this cross-linking. Proteases, such as elastase, are important in humans as they cleave peptide bonds and neutrophil granulocytes release specific elastase granules for killing microorganisms.

\section{Elastase}

Elastase in bacteria was isolated and described in 1960 $[64,65]$ and in fungi in 1967 [66] and many fungi have since been shown to have elastases [67]. Later it was found that proteases, such as elastase, are widely distributed in the human, bacterial, and fungal world [68,69]. Elastase was shown to promote fibroblast differentiation in lung fibrosis [70] and inhibiting elastase was shown in the bleomycinfibrosis model to prevent fibrosis [71]. Elastases in mammals are found mainly in pancreas and neutrophil granulocytes, and in macrophages while non-mammalian species show great variability of bacterial metallo- and serine- elastases [72] and the elastases are understood to be a virulence factor in bacteria such as Pseudomonas aeruginosa. Bacterial elastase was shown to cleave tight junctions as well as cleave $\operatorname{IgA}, \operatorname{IgG}, \mathrm{C} 3 \mathrm{bi}$, and CR1 contributing to decreased immune responses in the host [73]. Elastases belong to the class of serine proteinases, cysteine proteinases, and MMPs, and play seemingly important roles in both inflammation and fibrosis [72]. Elastase activity was demonstrated to be of importance for cancer invasion in human bladder cell lines in vitro; secreted elastase was shown only in $8 \%$ of samples revealing that elastase was primarily involved at the cell surface and not secreted by those cells [74].

Pancreatic elastase (PE) and neutrophil elastase (NE) were both isolated in pancreatic carcinoma cells and it was shown that these acinar enzymes are secreted in some $90 \%$ of patients with ductal adenocarcinoma [75]. Moreover, four of five pancreatic carcinoma cell lines expressed splicing variants of these enzymes.

Also, viruses code for proteinases but these differ significantly from cellular enzymes as the serine component is replaced by a cysteine residue [76]. Although many pathogenic mechanisms of viruses have not been elucidated, it is thought that proteases secreted in major target organs are of importance. One potential pathway for entry of the virus into the host might be due to proteases such as elastase $[77,78]$. This reveals that some pathogens enter the cell through their own proteases while others initiate protease secretion within the host.

It was shown in 1969 that cutaneous cells of glandular potential can be converted by the oncogenic virus, SV40, in vivo to adenocarcinomas. The authors showed that this is a rare event as only 4 out of 34 SV40 transformed embryonic skin and subcutaneous tissue cell lines developed an adenocarcinoma while the remaining 30 showed a variety of sarcomas [79]. Therefore, it seems not to be essential for a mesenchymal-epithelial or epithelialmesenchymal transition to occur but instead it appears critical that a cancer cell develops. Namiki et al. showed in 2009 that continuous exposure and infection with the bacterium mycoplasma, M. genitalium or M. hyorhinis, can lead into malignant transformation of benign human epithelial cells and served as an appropriate model to distinguish between prostatitis and prostatic carcinomas [80].

\section{Vimentin}

The intermediate filament, vimentin, maintains cellular architecture as well as tissue integrity and serves as a marker for cell transition $[81,82]$ as reported in sarcoma [83], in breast cancer [84-86] and in "various epithelial 
cancers including prostate cancer, gastrointestinal tumors, CNS tumors, breast cancer, malignant melanoma, lung cancer, and other types of cancers" (reviewed in [87]). It was suggested to be wary of using vimentin for cell transition as it is expressed in various cells, including fibroblasts, endothelial cells, cells of the hematopoietic lineages, and glial cells and because "adult epithelial cells transiently express vimentin in response to various insults" ([88] reviewed in [85]). As mentioned above, vimentin is also important for cell transition [89]. Furthermore, vimentin is correlated with mesenchymal cell shape and mobility which is associated with loss of desomosmal contacts [90] and which underpins why the assembly state of vimentin is sensitive altering stiffness and morphology [91]. Matrix stiffness triggers matrix MMPs activity, and matrix stiffness can, independently of matrix density, modify vascular growth and integrity [92].

A small GTPase of the Rab family, Rab7a, regulates cell migration through Ras-related C3 botulinum toxin substrate 1 (Rac1) and vimentin [93]. Here, there is an interconnection with Rac1: Lamellipodin is an actin regulator [94] and depletion decreases pulmonary metastasis in an orthotopic mouse breast cancer model and otherwise "Lamellipodin promotes invasive $3 D$ cancer cell migration via both actin-elongating Ena/VASP proteins and the Scar/WAVE complex" [95]. The Scar/WAVE complex is a co-factor and effector in cell migration $[96,97]$. Guanosine triphosphatase Rac-dependent ECM-stiffening involves focal adhesion kinase (FAK), the adaptor protein p130Cas (Cas), and lamellipodin by which mechanotransduction converts external information by the "ECM stiffness into stable intracellular stiffness and mechanosensitive cell cycling" showing that lamellipodin controls cell migration and directly influences and regulates the cell cycle [98]. There is hope that atomic force microscopy (AFM) can better characterizes ECM stiffness in the future [99].

Autophagy is inhibited by a protein kinase B (Akt-, PKB-)-dependent mechanism as vimentin forms a complex with 14-3-3 and beclin 1 and is a canonical marker of cell transition [81]. Higher expression levels of vimentin and positive N-Cadherin have been associated with poor survival and lower disease-free survival in patients with squamous cell carcinoma of the tongue which was significant even when using multivariate Cox regression with adjustments for cell differentiation, pathological stage, and expression levels of Snail, Twist, E-cadherin, and N-cadherin [100]. Vimentin was proposed to be essential in promoting metastatic potential in cholangiocellular carcinoma (CCC) [82]. Vimentin leads to a change of DNA architecture with chromatin disruption in human immunodeficiency virus type I (HIV-1) [101]. Vimentin is also upregulated in gastric cancer together with $\mathrm{N}$-cadherin and slug with downregulation of E-cadherin by the circular RNA circ104916 [102]. The fact that vimentin is routinely used for immunohistochemistry in mesenchymal tumors might be relevant and suggests that vimentin release plays a role in mesenchymal tumors.

\section{Fibronectin and decorin}

Fibronectins are large glycoproteins released by fibroblasts, macrophages, endothelial cells, chondrocytes, myoblasts, hepatocytes, and amniotic cells with small amounts also being released by intestinal epithelial cells (reviewed in [103]). Cellular fibronectin is typical as a fibrillar ECM although it can also be measured and found as soluble plasma fibronectin. Increased fibronectin levels had been found in benign hyperplasia and in various types of mammary tumors $([104,105]$ reviewed in $[106])$ which result in the proliferation and creation of an environment that facilitates cell growth. Increased rigidity occurs during the development of carcinogenesis and the ECM becomes stiff with altered signaling due to its stiffness ([107] reviewed in [106]).

An increase of fibronectin results in the reversal of cell growth arrest including failure to maintain the acinar structure. This is concordant with findings of increased fibronectin in breast cancers $[104,105]$. More rigid breast tissue is prone to develop hyperplasia and dysplasia including a direct association of density found in mammography and deposition of the proteoglycans, decorin and luminan, together with the presence of hyperplasia $([108,109]$ reviewed in [106]). It has been shown that increased fibronectin levels stimulate epithelial cells to produce their own fibronectin (reviewed in [106]).

Recently plenty of 113 ECM proteins measured by quantitative proteomics resulted into "ECM protein signatures unique to fibrosis, primary tumors, or metastases" [110]. These included several S100 proteins, including fibronectin and Tenascin-C (Tnc) in lung cancers and that tumor progression is induced by the transcription factor Nkx2-1 with subsequent Tnc repression. CRISPR-mediated Tnc activation resulted into metastatic dissemination. Within the cascade of pancreatic islets progression from being hyperplastic to angiogenic to insulinomas, 35 proteins of the ECM were detected in various abundance and "among these, the core ECM proteins, EFEMP1, fibrillin 1, and periostin were found in higher abundance, and decorin, Dmbt1, hemicentin, and Vwa5 in lower abundance" [111].

Despite various proteins, such as integrins, even fibronectins help various cancer-triggering pathogenic stimuli to bind such as has been shown for various herpes viruses [112-115], hepatitis viruses [116-118], schistosomiasis [119-123], or opisthorchis [124,125], helicobacter [126-129], or mycoplasma [130-134]. Otherwise autocrine fibronectin inhibits cancer spread [135] and decreased fibronectin seems to be essential during metastasis [136] as natural killer cells (NK cells) mediated control can inhibit metastasis by increase of fibronectin [137].

Recently, the influence of mycoplasma and the bacterial chaperon, DnaK, in carcinogenesis was shown to be dependent on p53 dysregulation [138]. The bacterial molecular chaperone DnaK family (70 kilodalton heat shock protein, Hsp70s) are UPs that are inactivated in an ATP-bound state and become 
activated by cellular stress to protect against aggregation. The DnaKs have been reported to be overexpressed in various cancers [139-142], their expression is reduced in esophageal cancers [143], and increased in virus replication [144]. However, the interaction of DnaK and cancer is not just dependent on p53 dysregulation which reveals that focusing on signaling pathways in carcinogenesis is not enough. Mycoplasma infection induces MMP-1 and MMP-9 [145], 5-lipoxygenase (5-LOX, ALOX5, 15-LO-1, 15-LOX-1) and cyclooxygenase 2 (Cox-2) [146], cytochrome P450, family 1, subfamily A, polypeptide 1 (CYP1A1) and interleukin 6 (IL-6) [147], plasmin [148], fibroblasts [149], p107 [150], IL-6, interleukin 1 beta (IL-1b), TGF-b and fibrosis [151], epidermal growth factor receptor (EGFR), phosphatidylinositide 3-kinase (PI3K), Akt, tumor suppressor phosphatase and tensin homolog (PTEN) and nuclear factor kappa-light-chain-enhancer of activated B cells (NF-кB) [152-154], deacetylates forkhead box protein O3a (FOXO3a) [155], and downregulates E-cadherin [156].

Furthermore, DnaK is upregulated in keloid tissues and scars [157] which can be basis for tumor development in various cancers [158-160]. In this regard, it may of importance to keep in mind the poor survival of subtypes of colorectal cancers with desmoplastic patterns [161] and the increase of desmoplasia in keloid tissues [162].

Decorin is a small $(90-140 \mathrm{kDa}$ in molecular weight) cellular and matrix glycosylated protein (proteoglycan) consisting of a chondroitin sulfate (CS) or dermatan sulfate (DS) encoded by the decorin gene and a component of the ECM $[163,164]$. The interaction of decorin with fibronectin inhibits fibroblast cell adhesion [165]. Decorin and fibromodulin are overexpressed in breast cancer cell lines associated with downregulation of activation of NF- $\kappa$ B and TGF- $\beta 1$ but fibromodulin has a more effective effect than decorin [166]. Decorin binds to TGF- $\beta$ stimulating Chinese hamster ovary (CHO) cell proliferation $[167,168]$. Decorin increases the phosphorylation level of TGF- $\beta$ receptor 1 (TGF- $\beta$ R 1 ) resulting in higher levels of TGF- $\beta$ receptor 2 (TGF- $\beta$ R2) as well as the expression of p15 with negative feedback on cell proliferation $[169,170]$. Ongoing TGF- $\beta 1$ signaling triggers an 8- to 10-fold increase of decorin some $48 \mathrm{~h}$ after TGF- $\beta$ exposure ceases and decorin binds fibronectin and collagen [171]. TGF- $\beta$ causes matrix accumulation through proteoglycan synthesis and deposition. Decorin is considered as a "guardian from the matrix" by modulation [172].

The proteoglycan, decorin, has regulatory effects on inflammation and cancer growth through the tumor suppressor programmed cell death 4 protein (PDCD4) and miR21 and acts "as an endogenous ligand of Toll-like receptors 2 and 4 and stimulates production of proinflammatory molecules, including PDCD4, in macrophages" [173] but otherwise decorin can increase TGF- $\beta$ activity [174]. Therefore, it seems that the general principle of homeostasis in biology also applies to decorin. Using an adenovirus gene transfer in the breast cancer cell line, 4T1, revealed a fibromodulin and decorin overexpression with downregulation of NF- $\mathrm{kB}$ and TGF- $\beta 1$ [166]. Decorin does not interact synergistically with TGF$\beta 2$ in the presence of fibronectin promoting cell migration, while in the presence of collagen TGF- $\beta 2$ fails to inhibit migration. This suggests that decorin can alter the activity of TGF- $\beta 2$ [175]. The disruption of decorin homeostasisis supported by the finding that cancer progression and poor prognosis in esophageal squamous cell carcinoma (ESCC) is associated with increased decorin levels [176]. Continuous TGF- $\beta$ overexpression may also leverage the negative feedback decorin mechanism with increases in cell proliferation.

\section{Summary}

UPs, once relegated to maintaining cellular structure and morphology, have in recent decades come to be recognized as components that effect the cross-linked ECM and the tumor environment. The language used by such proteins and their complementary enzymes with their influence on multiple pathways and the ECM is incompletely understood. Recent research has shown that UPs and their corresponding enzymes are actively involved early in carcinogenesis with consequent chronic inflammation, fibrosis, formation of the precancerous niche (PCN), chronic matrix stress escape attempts and, when these fail, transition of a normal cell to a cancer cell (NCCCT) occurs. Furthermore, UPs and their enzymes are involved in maintaining the cytoskeletal integrity, cell stability, information exchange by intercellular signaling, inhibition of autophagy and apoptosis. The degradation of UPs appears to be especially important for creating an environment that promotes the dissemination of cancer after a cancer cell has developed. The modulation of the microcosms with consequent dysregulated fine-tuning and induced crosstalk is influenced by UPs and their corresponding enzymes. These data warrant a much more refined examination of the qualitative and quantitative contribution of UPs and their enzymes during the "Disruption of signaling homeostasis induced crosstalk in the carcinogenesis paradigm Epistemology of the origin of cancer".

\section{Nomenclature}

$\begin{array}{ll}\text { 5-LOX } & \text { 5-Lipoxygenase (ALOX5, 15-LO-1, 15-LOX-1) } \\ \text { BAPN } & \text { 3-Amino-proprio-nitrile } \\ \text { AFM } & \text { Atomic force microscopy } \\ \text { AhR } & \text { Aryl hydrocarbon receptor } \\ \text { Akt } & \text { Protein kinase B (PKB) } \\ \text { C1M } & \text { Type I collagen } \\ \text { C4M } & \text { Type IV collagen } \\ \text { Cas } & \text { p130Cas } \\ \text { CCC } & \text { Cholangiocellular carcinoma } \\ \text { CHO } & \text { Chinese hamster ovary } \\ \text { CHOO } & \text { Acid amino group } \\ \text { Cox-2 } & \text { Cyclooxygenase 2 } \\ \text { CS } & \text { Chondroitin sulfate }\end{array}$




\begin{tabular}{|c|c|}
\hline CSC & Cancer stem cell \\
\hline CYP1A1 & $\begin{array}{l}\text { Cytochrome P450, family } 1 \text {, subfamily A, } \\
\text { polypeptide } 1\end{array}$ \\
\hline DNA & Deoxyribonucleic acid \\
\hline DnaK & 70 kilodalton heat shock protein, Hsp70s \\
\hline DS & Dermatan sulfate \\
\hline $\mathrm{E} 2 \mathrm{~F} 1$ & $\mathrm{E} 2 \mathrm{~F}$ transcription factor 1 \\
\hline ECM & Extracellular matrix \\
\hline EGFR & Epidermal growth factor receptor \\
\hline Erk1 & $\begin{array}{l}\text { Extracellular signal-regulated kinase } 1 \text {, } \\
\text { mitogen-activated protein kinase } 3 \text {, MAPK3 }\end{array}$ \\
\hline Erk2 & $\begin{array}{l}\text { Extracellular signal-regulated kinase } 2, \\
\text { mitogen-activated protein kinase 1, MAPK1 }\end{array}$ \\
\hline ESCC & Esophageal squamous cell carcinoma \\
\hline ETM & Epithelial-mesenchymal transition \\
\hline FAK & Focal adhesion kinase \\
\hline FGF & Fibroblast growth factor \\
\hline FGFR & Fibroblast growth factor receptor \\
\hline FGFR2b & Fibroblast growth factor receptor 2 \\
\hline FOXO3a & Forkhead box protein O3a \\
\hline Gly & Glycine \\
\hline $\mathrm{H} 3 \mathrm{~N} 2$ & Influenza A/Beijing/353/89 virus \\
\hline HAI-1 & Hepatocyte activator inhibitor type 1 \\
\hline HIV-1 & Human immunodeficiency virus Type I \\
\hline HPV16 E5 & $\begin{array}{l}\text { E5 oncoprotein of human papillomavirus } \\
\text { type } 16\end{array}$ \\
\hline Hsp70s & 70 kilodalton heat shock protein, DnaK \\
\hline IFN- $\beta$ & Interferon beta \\
\hline IL1-b & Interleukin 1 beta \\
\hline IL-6 & Interleukin 6 \\
\hline IRF-1 & Interferon regulatory factor 1 \\
\hline KGF & Keratinocyte growth factor \\
\hline KRTs & Keratins \\
\hline LOX & Lysyl oxidase \\
\hline MAPK1 & $\begin{array}{l}\text { Mitogen-activated protein kinase } 1 \text {, extra- } \\
\text { cellular signal-regulated kinase } 2, \text { Erk2 }\end{array}$ \\
\hline MAPK3 & $\begin{array}{l}\text { Mitogen-activated protein kinase } 3 \text {, extra- } \\
\text { cellular signal-regulated kinase } 1, \text { Erk1 }\end{array}$ \\
\hline MDCK & Madin-Darby canine kidney \\
\hline MMPs & Metalloproteinases \\
\hline MMP-1 & Metalloproteinase-1 \\
\hline MMP-2 & Metalloproteinase-2 \\
\hline MMP-9 & Metalloproteinase-9 \\
\hline MMP-13 & Metalloproteinase-13 \\
\hline NCCCT & Normal cell to a cancer cell transition \\
\hline $\mathrm{NE}$ & Neutrophil elastase \\
\hline NF-кB & $\begin{array}{l}\text { Nuclear factor kappa-light-chain-enhancer } \\
\text { of activated B cells }\end{array}$ \\
\hline NH2 & Basic amino group \\
\hline NK cells & Natural killer cells \\
\hline NRG & Neuregulin \\
\hline $\mathrm{PCN}$ & Precancerous niche \\
\hline PDCD4 & Programmed cell death 4 \\
\hline $\mathrm{PE}$ & Pancreatic elastase \\
\hline PERF I & Prospective epidemiologic risk factor I study \\
\hline PI3K & Phosphatidylinositide 3-kinase \\
\hline PKB & Protein kinase B (Akt) \\
\hline Pro & 4-Hydroxyproline \\
\hline PTEN & Phosphatase and tensin homolog \\
\hline
\end{tabular}

Rab7a Small GTPase of the Rab family

Rac1 Ras-related C3 botulinum toxin substrate 1

SBF1 Myotubularin-related protein 5

siAhR siRNA specific for AhR

Smad Intracellular protein transducing extracellular signals from TGF- $\beta$ ligands into the nucleus

SVAS Subvalvular aortic stenosis

TGF- $\beta 1$ Transforming growth factor beta 1

TGF- $\beta$ R $1 \quad$ TGF- $\beta$ receptor 1

TGF- $\beta$ R 2 TGF- $\beta$ receptor 2

Tnc Tenascin-C

UPs Ubiquitous proteins

VICM Citrullinated vimentin

\section{Acknowledgement}

The manuscripts of this Special Issue were supported by the Theodor-Billroth-Academy ${ }^{\circledR}\left(\mathrm{TBA}^{\circledR}\right)$ and INCORE, (International Consortium of Research Excellence) of the $\left(\right.$ TBA $\left.^{\circledR}\right)$. We express our gratitude to the discussions on the web group of the Theodor-Billroth-Academy ${ }^{\circledR}$ $\left(\mathrm{TBA}^{\circledR}\right)$ on LinkedIn, the exchange with scientists at Researchgate.com, as well as personal exchanges with distinguished colleagues who stimulated our thinking all named individually earlier in publications - we thank each one. We further gratefully acknowledge the support of Marjan S. Rupnik, PhD, Professor of Physiology, Institute of Physiology, Center for Physiology and Pharmacology, Medical University of Vienna, Austria, for pre-submission review of the literature and our fruitful discussions.

\section{Conflict of interest}

Björn L.D.M. Brücher is Editor-in-Chief in Life Sciences-Medicine of 4open by EDP Sciences. Ijaz S. Jamall is Senior Editorial Board member in Life SciencesMedicine of 4open by EDP Sciences. The authors, of their own initiative, suggested to the Managing Editorial to perform a transparent peer-review of their submittals. Neither author took any action to influence the standard submission and peer-review process, and report no conflict of interest. The authors alone are responsible for the content and writing of the manuscript of this Special Issue. This manuscript contains original material that has not previously been published. Both authors contributed to the discussion on its contents and approved the manuscript.

\section{References}

1. Harper HA, Martin DW, Mayes PA, Rodwell VW (Eds.) (1983), Review of biochemistry, 19th ed., Springer, New York, Berlin, Heidelberg.

2. Boon ME, Kok LP (1991), Formalin is deleterious to cytoskeleton proteins: do we need to replace it by formalin-free Kryofix? Eur J Morphol 29, 173-180. 
3. Azumi N, Battifora H (1987), The distribution of vimentin and keratin in epithelial and nonepithelial neoplasms. A comprehensive immunohistochemical study on formalinand alcohol-fixed tumors. Am J Clin Pathol 88, 286-296.

4. Alves VA, Wakamatsu A, Kanamura CT, Magalhäes ES, Siqueira SA (1992), The importance of fixation in immunohistochemistry: distribution of vimentin and cytokeratins in samples fixed in alcohol and formol. Rev Hosp Clin Fac Med Sao Paulo 47, 19-24.

5. von Weyhern CH, Brücher BLDM (2011), Application of laser microdissection and quantitative PCR to assess the response of esophageal cancer to neoadjuvant chemoradiotherapy. Methods Mol Biol 755, 197-202.

6. Benjamin E, Law S, Bobrow LG (1987), Intermediate filaments cytokeratin and vimentin in ovarian sex cordstromal tumours with correlative studies in adult and fetal ovaries. J Pathol 152, 253-263.

7. Hynes RO (2009), The extracellular matrix: not just pretty fibrils. Science 326, 1216-1219.

8. Rozario T, DeSimone DW (2010), The extracellular matrix in development and morphogenesis: a dynamic view. Dev Biol 341, 126-140.

9. Lu P, Takai K, Weaver VM, Werb Z (2011), Extracellular matrix degradation and remodeling in development and disease. Cold Spring Harb Perspect Biol 3, pii: a005058.

10. Oudin MJ, Jonas O, Kosciuk T, Broye LC, Guido BC, Wyckoff J, Riquelme D, Lamar JM, Asokan SB, Whittaker C, Ma D, Langer R, Cima MJ, Wisinski KB, Hynes RO, Lauffenburger DA, Keely PJ, Bear JE, Gertler FB (2016), Tumor cell-driven extracellular matrix remodeling drives haptotaxis during metastatic progression. Cancer Discov 6, 516-531.

11. Mohammadi M, Olsen SK, Goetz R (2005), A protein canyon in the FGF-FGF receptor dimer selects from an à la carte menu of heparan sulfate motifs. Curr Opin Struct Biol 15, 506-516.

12. Hynes RO, Naba A (2014), Overview of the matrisome-an inventory of extracellular matrix constituents and functions. Cold Spring Harb Perspect Biol 4, a004903.

13. Mouw JK, Ou G, Weaver VM (2014), Extracellular matrix assembly: a multiscale deconstruction. Nat Rev Mol Cell Biol 15, 771-785.

14. Naba A, Clauser KR, Hynes RO (2015), Enrichment of extracellular matrix proteins from tissues and digestion into peptides for mass spectrometry analysis. J Vis Exp e53057. DOI: $10.3791 / 53057$

15. Crewther WG, Fraser RDB, Lennox FG, Lindley $H$ (1965), The chemistry of keratins. Adv Protein Chem 20, 191-346.

16. Fraser RD, Macrae TP (1980), Molecular structure and mechanical properties of keratins. Symp Soc Exp Biol 34, 211-246.

17. Wang B, Yang W, McKittrick J, Meyers MA (2016), Keratin: structure, mechanical properties, occurrence in biological organisms, and efforts at bioinspiration. Prog Mater Sci 76, 229-318.

18. Moll R, Divo M, Langbein L (2008), The human keratins: biology and pathology. Histochem Cell Biol 129, 705-733.

19. Rogers MA, Langbein L, Praetzel-Wunder S, Winter H, Schweizer J (2006), Human hair keratin-associated proteins (KAPs). Int Rev Cytol 251, 209-263.

20. Wu DD, Irwin DM, Zhang YP (2008), Molecular evolution of the keratin associated protein gene family in mammals, role in the evolution of mammalian hair. BMC Evol Biol 8, 241.
21. Margolis SS, Perry JA, Forester CM, Nutt LK, Guo Y, Jardim MJ, Thomenius MJ, Freel CD, Darbandi R, Ahn JH, Arroyo JD, Wang XF, Shenolikar S, Nairn AC, Dunphy WG, Hahn WC, Virshup DM, Kornbluth S (2006), Role for the PP2A/B56delta phosphatase in regulating 14-3-3 release from Cdc25 to control mitosis. Cell 127, 759-773.

22. Hanukoglu I, Fuchs E (1982), The cDNA sequence of a human epidermal keratin: divergence of sequence but conservation of structure among intermediate filament proteins. Cell 31, 243-252.

23. Lee CH, Kim MS, Chung BM, Leahy DJ, Coulombe PA (2012), Structural basis for heteromeric assembly and perinuclear organization of keratin filaments. Nat Struct Mol Biol 19, 707-715.

24. Schweizer J, Bowden PE, Coulombe PA, Langbein L, Lane EB, Magin TM, Maltais L, Omary MB, Parry DA, Rogers MA, Wright MW (2006), New consensus nomenclature for mammalian keratins. J Cell Biol 174, 169-174.

25. Plowman JE (2007), The proteomics of keratin proteins. J Chromatogr B Analyt Technol Biomed Life Sci 849, 181-189.

26. Kawaguchi M, Kanemaru A, Sawaguchi A, Yamamoto K, Baba T, Lin CY, Johnson MD, Fukushima T, Kataoka H (2015), Hepatocyte growth factor activator inhibitor type 1 maintains the assembly of keratin into desmosomes in keratinocytes by regulating proteaseactivated receptor 2-dependent p38 signaling. Am J Pathol 185, 1610-1623.

27. Kawai T, Yasuchika K, Ishii T, Katayama H, Yoshitoshi EY, Ogiso S, Kita S, Yasuda K, Fukumitsu K, Mizumoto M, Hatano E, Uemoto S (2015), Keratin 19, a cancer stem cell marker in human hepatocellular carcinoma. Clin Cancer Res 21, 3081-3091.

28. Bonin S, Pracella D, Barbazza R, Sulfaro S, Stanta G (2015), In stage II/III lymph node-positive breast cancer patients less than 55 years of age, keratin 8 expression in lymph node metastases but not in the primary tumour is an indicator of better survival. Virchows Arch 466, $571-580$.

29. Safall H, Azar HA (1966), Keratin granulomas in irradiated squamous cell carcinoma of various sites. Cancer Res 26, 500-508.

30. Hall JW, Friedman M (1948), Histologic changes in squamous-cell carcinoma of the mouth and oropharynx produced by fractional external roentgen irradiation. Radiology 50, 318-350.

31. Pastuszak M, Groszewski K, Pastuszak M, Dyrla P, Wojtun S, Gil J (2015), Cytokeratins in gastroenterology. Systematic review. Prz Gastroenterol 10, 61-70.

32. Lavallard VJ, Bonnafous S, Patouraux S, Saint-Paul MC, Rousseau D, Anty R, Le Marchand-Brustel Y, Tran A, Gual P (2011), Serum markers of hepatocyte death and apoptosis are non invasive biomarkers of severe fibrosis in patients with alcoholic liver disease. PLoS One 6 , e17599.

33. Gupta R, Rajput R, Sharma R, Gupta N (2013), Biotechnological applications and prospective market of microbial keratinases. Appl Microbiol Biotechnol 97, 9931-9940.

34. Daroit DJ, Brandelli A (2003), A current assessment on the production of bacterial keratinases. Crit Rev Biotechnol 34, 372-384.

35. Molyneux GS (1959), The digestion of wool by a keratinolytic Bacillus. Aust J Biol Sci 12, 274-281. 
36. Noval JJ, Nickerson WJ (1959), Decomposition of native keratin by Streptomyces fradiae. J Bacteriol 77, 251-263.

37. Safranek WW, Goos RD (1982), Degradation of wool by saprophytic fungi. Can J Microbiol 28, 137-140.

38. Dahl MV (1994), Dermatophytosis and the immune response. J Am Acad Dermatol 31, 34-41.

39. Bockle B, Muller R (1997), Reduction of disulfide bonds by Streptomyces pactum during growth on chicken feathers. Appl Environ Microbiol 63, 790-792.

40. Rubin JS, Osada H, Finch PW, Taylor WG, Rudikoff S, Aaronson SA (1989), Purification and characterization of a newly identified growth factor specific for epithelial cells. Proc Natl Acad Sci USA 86, 802-806.

41. Nakazawa K, Yashiro M, Hirakawa K (2003), Keratinocyte growth factor produced by gastric fibroblasts specifically stimulates proliferation of cancer cells from scirrhous gastric carcinoma. Cancer Res 63, 8848-8852.

42. Finch PW, Rubin JS, Miki T, Ron D, Aaronson SA (1989), Human KGF is FGF related with properties of a paracrine effector of epithelial cell growth. Science 245, $752-755$.

43. Miki T, Bottaro DP, Fleming TP, Smith CL, Burgess WH, Chan AM, Aaronson SA (1992), Determination of ligandbinding specificity by alternative splicing: two distinct growth factor receptors encoded by a single gene. Proc Natl Acad Sci USA 89, 246-250.

44. Raffa S, Leone L, Scrofani C, Monini S, Torrisi MR, Barbara M (2012), Cholesteatoma-associated fibroblasts modulate epithelial growth and differentiation through KGF/FGF7 secretion. Histochem Cell Biol 138, 251-269.

45. Belleudi F, Leone L, Purpura V, Cannella F, Scrofani C, Torrisi MR (2011), HPV16 E5 affects the KGFR/ FGFR2b-mediated epithelial growth through alteration of the receptor expression, signaling and endocytic traffic. Oncogene 30, 4963-4976.

46. Ranieri D, Belleudi F, Magenta A, Torrisi MR (2015), HPV16 E5 expression induces switching from FGFR2b to FGFR2c and epithelial-mesenchymal transition. Int J Cancer 137, 61-72.

47. Muto V, Stellacci E, Lamberti AG, Perrotti E, Carrabba A, Matera G, Sgarbanti M, Battistini A, Liberto MC, Focà A (2011), Human papillomavirus type 16 E5 protein induces expression of beta interferon through interferon regulatory factor 1 in human keratinocytes. J Virol 85, 5070-5080.

48. Yang K, Yin J, Sheng B, Wang Q, Han B, Pu A, Yu M, Sun L, Xiao W, Yang H (2017), AhR-E2F1-KGFR signaling is involved in KGF-induced intestinal epithelial cell proliferation. Mol Med Rep 15, 3019-3026.

49. Araldi RP, Assaf SMR, Carvalho RF, Carvalho MACR, Souza JM, Magnelli RF, Módolo DG, Roperto FP, Stocco RC, Beçak W (2017), Papillomaviruses: a systematic review. Genet Mol Biol 40, 1-21.

50. Astbury WT, Bell FO (1940), The molecular structure of the fibers of the collagen group. Nature 145, 421-422.

51. Pauling L, Corey RB (1951), The structure of fibrous proteins of the collagen-gelatin group. Proc Natl Acad Sci USA 37, 272-281.

52. Shoulders MD, Raines RT (2009), Collagen structure and stability. Annu Rev Biochem 78, 929-958.

53. Nimni ME (1977), Mechanism of inhibition of collagen crosslinking by penicillamine. Proc $\mathrm{R}$ Soc Med 70 , $65-72$.
54. Lazarus GS, Daniels JR, Lian J, Burleigh MC (1972), Role of granulocyte collagenase in collagen degradation. Am J Pathol 68, 565-578.

55. Duffy MJ, Maguire TM, Hill A, McDermott E, O'Higgins N (2000), Metalloproteinases: role in breast carcinogenesis, invasion and metastasis. Breast Cancer Res 2, $252-257$.

56. Bager CL, Willumsen N, Kehlet SN, Hansen HB, BayJensen AC, Leeming DJ, Dragsbæk K, Neergaard JS, Christiansen C, Høgdall E, Karsdal M (2016), Remodeling of the tumor microenvironment predicts increased risk of cancer in postmenopausal women: the prospective epidemiologic risk factor (PERF I) study. Cancer Epidemiol Biomark Prev 25, 1348-1355.

57. Yeo SJ, Kim SJ, Kim JH, Lee HJ, Kook YH (1999), Influenza A virus infection modulates the expression of type IV collagenase in epithelial cells. Arch Virol 144, 1361-1370.

58. Agha-Hosseini F, Mirzaii-Dizgah I (2015), Serum and saliva collagenase-3 (MMP-13) in patients with oral lichen planus and oral squamous cell carcinoma. Med J Islam Repub Iran 29, 218. eCollection 2015.

59. Seoane S, Montero JC, Ocaña A, Pandiella A (2016), Breast cancer dissemination promoted by a neuregulincollagenase 3 signalling node. Oncogene 35, 2756-2765.

60. Jackson JG, Orr JW (1957), The ducts of carcinomatous breasts, with particular reference to connective-tissue changes. J Pathol Bacterial 74, 265-273.

61. Ozzello L, Sanpitak P (1970), Epithelial-stromal junction of intraductal carcinoma of the breast. Cancer 26, $1186-1198$.

62. Lundmark C (1972), Breast cancer and elastosis. Cancer 30, 1195-1201.

63. Bereiter-Hahn J, Matoltsy AG, Richards KS (Eds.) (2013), Biology of the integument: 2 vertebrates, Springer Science \& Business Media, Berlin.

64. Mandl I, Cohen BB (1960), Bacterial elastase. I. Isolation, purification and properties. Arch Biochem Biophys 91, $47-53$.

65. Sbarra AJ, Baumstark JS, Gilfillan RF, Bardawil WA (1963), Elastase production by micro-organisms. Nature 197, 153-155.

66. Rippon JW (1967), Elastase: production by ringworm fungi. Science 157, 947.

67. Rippon JW, Hoo MS (1971), Determination of fungal elastase. Appl Microbiol 22, 471-472.

68. Unanue ER, Beller DI, Calderon J, Kiely JM, Stadecker MJ (1976), Regulation of immunity and inflammation by mediators from macrophages. Am J Pathol 85, 465-478.

69. Häse CC, Finkelstein RA (1993), Bacterial extracellular zinc-containing metalloproteases. Microbiol Rev 57, 823-837.

70. Gregory AD, Kliment CR, Metz HE, Kim KH, Kargl J, Agostini BA, Crum LT, Oczypok EA, Oury TA, Houghton AM (2015), Neutrophil elastase promotes myofibroblast differentiation in lung fibrosis. J Leukoc Biol 98, 143-152.

71. Takemasa A, Ishii Y, Fukuda T (2012), A neutrophil elastase inhibitor prevents bleomycin-induced pulmonary fibrosis in mice. Eur Respir J 40, 1475-1482.

72. Bieth JG (2001), The elastases. J Soc Biol 195, 173-179.

73. Heck LW, Alarcon PG, Kulhavy RM, Morihara K, Russell MW, Mestecky JF (1990), Degradation of IgA proteins by Pseudomonas aeruginosa elastase. J Immunol 144, 2253-2257. 
74. Grant AJ, Russell PJ, Raghavan D (1989), Elastase activities of human bladder cancer cell lines derived from high grade invasive tumours. Biochem Biophys Res Commun 162, 308-315.

75. Shimada S, Yamaguchi K, Takahashi M, Ogawa M (2002), Pancreatic elastase IIIA and its variants are expressed in pancreatic carcinoma cells. Int J Mol Med 10, 599-603.

76. Bazan JF, Fletterick RJ (1988), Viral cysteine proteases are homologous to the trypsin-like family of serine proteases: structural and functional implications. Proc Natl Acad Sci USA 86, 7872-7876.

77. Matsuyama S, Ujike M, Morikawa S, Tashiro M, Taguchi F (2005), Protease-mediated enhancement of severe acute respiratory syndrome coronavirus infection. Proc Natl Acad Sci USA 102, 12543-12547.

78. Belouzard S, Madu I, Whittaker GR (2010), Elastasemediated activation of the severe acute respiratory syndromecoronavirus spike protein at discrete sites within the S2 domain. J Biol Chem 285, $22758-22763$.

79. Diamandopoulos GT, Dalton-Tucker MF (1969), Induction in hamsters of various carcinomas and sarcomas by in-vitro SV40-transformed homologous embryonic skin and subcutaneous tissue cells. Role of target cells in determining tumor morphology. Am J Pathol 56, 59-77.

80. Namiki K, Goodison S, Porvasnik S, Allan RW, Iczkowski KA, Urbanek C, Reyes L, Sakamoto N, Rosser CJ (2009), Persistent exposure to Mycoplasma induces malignant transformation of human prostate cells. PLoS One 4, e6872.

81. Kidd ME, Shumaker DK, Ridge KM (2014), The role of vimentin intermediate filaments in the progression of lung cancer. Am J Respir Cell Mol Biol 50, 1-6.

82. Saentaweesuk W, Araki N, Vaeteewoottacharn K, Silsirivanit A, Seubwai W, Talabnin C, Muisuk K, Sripa B, Wongkham S, Okada S, Wongkham C (2018), Activation of vimentin is critical to promote a metastatic potential of cholangiocarcinoma cells. Oncol Res 26, 605-616.

83. Leader M, Collins M, Patel J, Henry K (1987), Vimentin: an evaluation of its role as a tumour marker. Histopathology $11,63-72$.

84. Sommers CL, Walker-Jones D, Heckford SE, Worland P, Valverius E, Clark R, McCormick F, Stampfer M, Abularach S, Gelmann EP (1989), Vimentin rather than keratin expression in some hormone-independent breast cancer cell lines and in oncogene-transformed mammary epithelial cells. Cancer Res 49, 4258-4263.

85. Zeisberg M, Neilson EG (2009), Biomarkers for epithelial-mesenchymal transitions. J Clin Invest 119, 1429-1437.

86. Sethi S, Sarkar FH, Ahmed Q, Bandyopadhyay S, Nahleh ZA, Semaan A, Sakr W, Munkarah A, Ali-Fehmi R (2011), Molecular markers of epithelial-to-mesenchymal transition are associated with tumor aggressiveness in breast carcinoma. Transl Oncol 4, 222-226.

87. Satelli A, Li S (2011), Vimentin in cancer and its potential as a molecular target for cancer therapy. Cell Mol Life Sci 68, 3033-3046.

88. Witzgall R, Brown D, Schwarz C, Bonventre JV (1994), Localization of proliferating cell nuclear antigen, vimentin, c-Fos, and clusterin in the postischemic kidney. Evidence for a heterogenous genetic response among nephron segments, and a large pool of mitotically active and dedifferentiated cells. J Clin Invest 93, 2175-2188.
89. Thiery JP (2002), Epithelial-mesenchymal transitions in tumour progression. Nat Rev Cancer 2, 442-454.

90. Mendez MG, Kojima S, Goldman RD (2010), Vimentin induces changes in cell shape, motility, and adhesion during the epithelial to mesenchymal transition. FASEB J $24,1838-1851$

91. Murray ME, Mendez MG, Janmey PA (2014), Substrate stiffness regulates solubility of cellular vimentin. Mol Biol Cell 25, 87-94.

92. Bordeleau F, Mason BN, Lollis EM, Mazzola M, Zanotelli MR, Somasegar S, Califano JP, Montague C, LaValley DJ, Huynh J, Mencia-Trinchant N, Negrón Abril YL, Hassane DC, Bonassar LJ, Butcher JT, Weiss RS, Reinhart-King CA (2017), Matrix stiffening promotes a tumor vasculature phenotype. Proc Natl Acad Sci USA 114, 492-497.

93. Margiotta A, Progida C, Bakke O, Bucci C (2017), Rab7a regulates cell migration through Rac1 and vimentin. Biochim Biophys Acta Mol Cell Res 1864, 367-381.

94. Krause M, Leslie JD, Stewart M, Lafuente EM, Valderrama F, Jagannathan R, Strasser GA, Rubinson DA, Liu H, Way M, Yaffe MB, Boussiotis VA, Gertler FB (2004), Lamellipodin, an Ena/VASP ligand, is implicated in the regulation of lamellipodial dynamics. Dev Cell 7, 571-583.

95. Carmona G, Perera U, Gillett C, Naba A, Law AL, Sharma VP, Wang J, Wyckoff J, Balsamo M, Mosis F, De Piano M, Monypenny J, Woodman N, McConnell RE, Mouneimne G, Van Hemelrijck M, Cao Y, Condeelis J, Hynes RO, Gertler FB, Krause M (2016), Lamellipodin promotes invasive $3 \mathrm{D}$ cancer cell migration via regulated interactions with Ena/VASP and SCAR/WAVE. Oncogene $35,5155-5169$.

96. Insall RH, Machesky LM (2009), Actin dynamics at the leading edge: from simple machinery to complex networks. Dev Cell 17, 310-322.

97. Law AL, Vehlow A, Kotini M, Dodgson L, Soong D, Theveneau E, Bodo C, Taylor E, Navarro C, Perera U, Michael M, Dunn GA, Bennett D, Mayor R, Krause M (2013), Lamellipodin and the Scar/WAVE complex cooperate to promote cell migration in vivo. J Cell Biol 203, 673-689.

98. Bae YH, Mui KL, Hsu BY, Liu SL, Cretu A, Razinia Z, Xu T, Puré E, Assoian RK (2014), A FAK-Cas-Raclamellipodin signaling module transduces extracellular matrix stiffness into mechanosensitive cell cycling. Sci Signal 7, ra57.

99. Bae YH, Liu SL, Byfield FJ, Janmey PA, Assoian RK (2016), Measuring the stiffness of ex vivo mouse aortas using atomic force microscopy. J Vis $\operatorname{Exp}(116)$. DOI: $10.3791 / 54630$

100. Liu PF, Kang BH, Wu YM, Sun JH, Yen LM, Fu TY, Lin YC, Liou HH, Lin YS, Sie HC, Hsieh IC, Tseng YK, Shu CW, Hsieh YD, Ger LP (2017), Vimentin is a potential prognostic factor for tongue squamous cell carcinoma among five epithelial-mesenchymal transition-related proteins. PLoS One 12, e0178581.

101. Shoeman RL, Hüttermann C, Hartig R, Traub P (2001), Amino-terminal polypeptides of vimentin are responsible for the changes in nuclear architecture associated with human immunodeficiency virus type 1 protease activity in tissue culture cells. Mol Biol Cell 12, 143-154.

102. Li R, Dong T, Hu C, Lu J, Dai J, Liu P (2017), Salinomycin repressed the epithelial-mesenchymal transition of epithelial ovarian cancer cells via downregulating Wnt/ $\beta$-catenin pathway. Onco Targets Ther 10, 1317-1325.

103. Hynes RO, Yamada KM (1982), Fibronectins: multifunctional modular glycoproteins. J Cell Biol 95, 369-377. 
104. Christensen L (1992), The distribution of fibronectin, laminin and tetranectin in human breast cancer with special attention to the extracellular matrix. APMIS Suppl 26, 1-39.

105. Koukoulis GK, Howeedy AA, Korhonen M, Virtanen I, Gould VE (1993), Distribution of tenascin, cellular fibronectins and integrins in the normal, hyperplastic and neoplastic breast. J Submicrosc Cytol Pathol 25, 285-295.

106. Williams CM, Engler AJ, Slone RD, Galante LL, Schwarzbauer JE (2008), Fibronectin expression modulates mammary epithelial cell proliferation during acinar differentiation. Cancer Res 68, 3185-3192.

107. Paszek MJ, Zahir N, Johnson KR, Lakins JN, Rozenberg GI, Gefen A, Reinhart-King CA, Margulies SS, Dembo M, Boettiger D, Hammer DA, Weaver VM (2005), Tensional homeostasis and the malignant phenotype. Cancer Cell 8, $241-254$

108. Boyd NF, Jensen HM, Cooke G, Han HL (1992), Relationship between mammographic and histological risk factors for breast cancer. J Natl Cancer Inst 84, 1170-1179.

109. Alowami S, Troup S, Al-Haddad S, Kirkpatrick I, Watson PH (2003), Mammographic density is related to stroma and stromal proteoglycan expression. Breast Cancer Res 5, R129-R135.

110. Gocheva V, Naba A, Bhutkar A, Guardia T, Miller KM, Li CM, Dayton TL, Sanchez-Rivera FJ, Kim-Kiselak C, Jailkhani N, Winslow MM, Del Rosario A, Hynes RO, Jacks T (2017), Quantitative proteomics identify Tenascin-C as a promoter of lung cancer progression and contributor to a signature prognostic of patient survival. Proc Natl Acad Sci USA 114, E5625-E5634.

111. Naba A, Clauser KR, Mani DR, Carr SA, Hynes RO (2017), Quantitative proteomic profiling of the extracellular matrix of pancreatic islets during the angiogenic switch and insulinoma progression. Sci Rep 7, 40495.

112. Wilson AC, Boutros M, Johnson KM, Herr W (2000), HCF-1 amino- and carboxy-terminal subunit association through two separate sets of interaction modules: involvement of fibronectin type 3 repeats. Mol Cell Biol 20, 6721-6730.

113. Sharma-Walia N, Paul AG, Bottero V, Sadagopan S, Veettil MV, Kerur N, Chandran B (2010), Kaposi's sarcoma associated herpes virus (KSHV) induced COX-2: a key factor in latency, inflammation, angiogenesis, cell survival and invasion. PLoS Pathog 6, e1000777.

114. Park J, Lammers F, Herr W, Song JJ (2012), HCF-1 selfassociation via an interdigitated Fn3 structure facilitates transcriptional regulatory complex formation. Proc Natl Acad Sci USA 109, 17430-17435.

115. Grosche L, Draßner C, Mühl-Zürbes P, Kamm L, LeTrilling VTK, Trilling M, Steinkasserer A, Heilingloh CS (2017), Human cytomegalovirus-induced degradation of CYTIP modulates dendritic cell adhesion and migration. Front Immunol 8, 461.

116. Yang J, Ding X, Zhang Y, Bo X, Zhang M, Wang S (2006), Fibronectin is essential for hepatitis $\mathrm{B}$ virus propagation in vitro: may be a potential cellular target? Biochem Biophys Res Commun 344, 757-764.

117. Yang J, Wang F, Tian L, Su J, Zhu X, Lin L, Ding X, Wang X, Wang S (2010), Fibronectin and asialoglyprotein receptor mediate hepatitis $\mathrm{B}$ surface antigen binding to the cell surface. Arch Virol 155, 881-888.

118. Ren S, Wang J, Chen TL, Li HY, Wan YS, Peng NF, Gui XE, Zhu Y (2016), Hepatitis B virus stimulated fibronectin facilitates viral maintenance and replication through two distinct mechanisms. PLoS One 11, e0152721.
119. Al Adnani MS (1985), Concomitant immunohistochemical localization of fibronectin and collagen in schistosome granulomata. J Pathol 147, 77-85.

120. Wyler DJ, Ehrlich HP, Postlethwaite AE, Raghow R, Murphy MM (1987), Fibroblast stimulation in schistosomiasis. VII. Egg granulomas secrete factors that stimulate collagen and fibronectin synthesis. J Immunol 138, 1581-1586.

121. Zhu Y (1996), Fibronectin co-stimulates via the alpha 5 beta 1 receptor IL-2, IL-4 production by splenic, granuloma lymphocytes of Schistosoma mansoni infected mice. Scand J Immunol 43, 633-639.

122. Hussein MR, Nassar MI, Kamel NA, Osman ME, Georguis MN (2005), Analysis of fibronectin expression in the bilharzial granulomas and of laminin in the transformed urothelium in schistosoma haematobium infested patients. Cancer Biol Ther 4, 676-678.

123. Luo J, Liang Y, Kong F, Qiu J, Liu X, Chen A, Luxon BA, Wu HW, Wang Y (2017), Vascular endothelial growth factor promotes the activation of hepatic stellate cells in chronic schistosomiasis. Immunol Cell Biol 95, 399-407.

124. Khoontawad J, Laothong U, Roytrakul S, Pinlaor P, Mulvenna J, Wongkham C, Yongvanit P, Pairojkul C, Mairiang E, Sithithaworn P, Pinlaor S (2012), Proteomic identification of plasma protein tyrosine phosphatase alpha and fibronectin associated with liver fluke. Opisthorchis viverrini, infection. PLoS One 7, e45460.

125. Charoensuk L, Pinlaor P, Wanichwecharungruang S, Intuyod K, Vaeteewoottacharn K, Chaidee A, Yongvanit P, Pairojkul C, Suwannateep N, Pinlaor S (2016), Nanoencapsulated curcumin and praziquantel treatment reduces periductal fibrosis and attenuates bile canalicular abnormalities in Opisthorchis viverrini-infected hamsters. Nanomedicine 12, 21-32.

126. Lim JW, Kim H, Kim KH (2003), Cell adhesion-related gene expression by Helicobacter pylori in gastric epithelial AGS cells. Int J Biochem Cell Biol 35, 1284-1296.

127. Hennig EE, Godlewski MM, Butruk E, Ostrowski J (2005), Helicobacter pylori VacA cytotoxin interacts with fibronectin and alters HeLa cell adhesion and cytoskeletal organization in vitro. FEMS Immunol Med Microbiol 44, 143-150.

128. Tegtmeyer N, Hartig R, Delahay RM, Rohde M, Brandt S, Conradi J, Takahashi S, Smolka AJ, Sewald N, Backert S (2010), A small fibronectin-mimicking protein from bacteria induces cell spreading and focal adhesion formation. J Biol Chem 285, 23515-23526.

129. Pachathundikandi SK, Tegtmeyer N, Backert S (2013), Signal transduction of Helicobacter pylori during interaction with host cell protein receptors of epithelial and immune cells. Gut Microbes 4, 454-474.

130. Yavlovich A, Rottem S (2007), Binding of host extracellular matrix proteins to Mycoplasma fermentans and its effect on adherence to, and invasion of HeLa cells. FEMS Microbiol Lett 266, 158-162.

131. Balasubramanian S, Kannan TR, Hart PJ, Baseman JB (2009), Amino acid changes in elongation factor $\mathrm{Tu}$ of Mycoplasma pneumoniae and Mycoplasma genitalium influence fibronectin binding. Infect Immun 77, 3533-3541.

132. Yu Y, Liu M, Hua L, Qiu M, Zhang W, Wei Y, Gan Y, Feng Z, Shao G, Xiong Q (2018), Fructose-1,6-bisphosphate aldolase encoded by a core gene of Mycoplasma hyopneumoniae contributes to host cell adhesion. Vet Res 49, 114

133. Chen X, Huang J, Zhu H, Guo Y, Khan FA, Menghwar H, Zhao G, Guo A (2018), P27 (MBOV_RS03440) is a novel fibronectin binding adhesin of Mycoplasma bovis. Int J Med Microbiol 308, 848-857. 
134. Yu Y, Wang H, Wang J, Feng Z, Wu M, Liu B, Xin J, Xiong Q, Liu M, Shao G (2018), Elongation Factor Thermo Unstable (EF-Tu) Moonlights as an Adhesin on the Surface of Mycoplasma hyopneumoniae by Binding to Fibronectin. Front Microbiol 9, 974.

135. Shinde A, Libring S, Alpsoy A, Abdullah A, Schaber JA, Solorio L, Wendt MK (2018), Autocrine Fibronectin Inhibits Breast Cancer Metastasis. Mol Cancer Res 16, $1579-1589$.

136. Zhang X, Liu S, Hu T, Liu S, He Y, Sun S (2009), Upregulated microRNA-143 transcribed by nuclear factor kappa B enhances hepatocarcinoma metastasis by repressing fibronectin expression. Hepatology 50, 490-499.

137. Glasner A, Levi A, Enk J, Isaacson B, Viukov S, Orlanski S, Scope A, Neuman T, Enk CD, Hanna JH, Sexl V, Jonjic S, Seliger B, Zitvogel L, Mandelboim O (2018), NKp46 receptor-mediated interferon- $\gamma$ production by natural killer cells increases fibronectin 1 to alter tumor architecture and control metastasis. Immunity 48, 107.e4-119.e4.

138. Zella D, Curreli S, Benedetti F, Krishnan S, Cocchi F, Latinovic OS, Denaro F, Romerio F, Djavani M, Charurat ME, Bryant JL, Tettelin H, Gallo RC (2018), Mycoplasma promotes malignant transformation in vivo, and its DnaK, a bacterial chaperon protein, has broad oncogenic properties. Proc Natl Acad Sci USA pii:201815660. DOI: 10.1073 /pnas. 1815660115

139. Mivechi NF, Rossi JJ (1990), Use of polymerase chain reaction to detect the expression of the Mr 70,000 heat shock genes in control or heat shock leukemic cells as correlated to their heat response. Cancer Res 50, $2877-2884$.

140. Lazaris AC, Theodoropoulos GE, Davaris PS, Panoussopoulos D, Nakopoulou L, Kittas C, Golematis BC (1995), Heat shock protein 70 and HLA-DR molecules tissue expression. Prognostic implications in colorectal cancer. Dis Colon Rectum 38, 739-745.

141. Ricaniadis N, Kataki A, Agnantis N, Androulakis G, Karakousis CP (2001), Long-term prognostic significance of HSP-70, c-myc and HLA-DR expression in patients with malignant melanoma. Eur J Surg Oncol 27, 88-93.

142. Sagol O, Tuna B, Coker A, Karademir S, Obuz F, Astarcioglu H, Küpelioglu A, Astarcioglu I, Topalak O (2002), Immunohistochemical detection of pS2 protein and heat shock protein-70 in pancreatic adenocarcinomas. Relationship with disease extent and patient survival. Pathol Res Pract 198, 77-84.

143. Kawanishi K, Shiozaki H, Doki Y, Sakita I, Inoue M, Yano M, Tsujinaka T, Shamma A, Monden M (1999), Prognostic significance of heat shock proteins 27 and 70 in patients with squamous cell carcinoma of the esophagus. Cancer 85, 1649-1657.

144. LaThangue NB, Latchman DS (1987), Nuclear accumulation of a heat-shock 70-like protein during herpes simplex virus replication. Biosci Rep 7, 475-483.

145. Baluk P, Raymond WW, Ator E, Coussens LM, McDonald DM, Caughey GH (2004), Matrix metalloproteinase-2 and -9 expression increases in Mycoplasma-infected airways but is not required for microvascular remodeling. Am J Physiol Lung Cell Mol Physiol 287, L307-L317.

146. Giacominelli-Stuffler R, Marruchella G, Storelli MM, Sabatucci A, Angelucci CB, Maccarrone M (2012), 5 -Lipoxygenase and cyclooxygenase-2 in the lungs of pigs naturally affected by enzootic pneumonia and porcine pleuropneumonia. Res Vet Sci 93, 898-903.
147. Zhao J, Zhang W, Shen L, Yang X, Liu Y, Gai Z (2017), Association of the ACE, GSTM1, IL-6, NOS3, and CYP1A1 polymorphisms with susceptibility of mycoplasma pneumoniae pneumonia in Chinese children. Medicine (Baltimore) 96, e6642.

148. Hagemann L, Gründel A, Jacobs E, Dumke R (2017), The surface-displayed chaperones GroEL and DnaK of Mycoplasma pneumoniae interact with human plasminogen and components of the extracellular matrix. Pathog Dis 75. DOI: $10.1093 /$ femspd/ftx017

149. Gomersall AC, Phan HA, Iacuone S, Li SF, Parish RW (2015), The Mycoplasma hyorhinis p37 protein rapidly induces genes in fibroblasts associated with inflammation and cancer. PLoS One 10, e0140753.

150. Horowitz S, Evinson B, Borer A, Horowitz J (2000), Mycoplasma fermentans in rheumatoid arthritis and other inflammatory arthritides. J Rheumatol 27, 2747-2753.

151. Lin Y, Tan D, Kan Q, Xiao Z, Jiang Z (2018), The protective effect of naringenin on airway remodeling after Mycoplasma Pneumoniae infection by inhibiting autophagy-mediated lung inflammation and fibrosis. Mediators Inflamm 2018, 8753894.

152. Huang G, Redelman-Sidi G, Rosen N, Glickman MS, Jiang X (2012), Inhibition of mycobacterial infection by the tumor suppressor PTEN. J Biol Chem 287, 23196-23202.

153. Duan H, Qu L, Shou C (2014), Activation of EGFR-PI3KAKT signaling is required for Mycoplasma hyorhinispromoted gastric cancer cell migration. Cancer Cell Int 14, 135.

154. Yuan B, Zou M, Zhao Y, Zhang K, Sun Y, Peng X (2018), Up-regulation of miR-130b-3p activates the PTEN/ $\mathrm{PI} 3 \mathrm{~K} / \mathrm{AKT} / \mathrm{NF}-\kappa \mathrm{B}$ pathway to defense against Mycoplasma gallisepticum (HS strain) infection of chicken. Int J Mol Sci 19, pii: E2172.

155. Cheng Q, Wu L, Tu R, Wu J, Kang W, Su T, Du R, Liu W (2017), Mycoplasma fermentans deacetylase promotes mammalian cell stress tolerance. Microbiol Res $201,1-11$.

156. Obara H, Harasawa R (2010), Nitric oxide causes anoikis through attenuation of E-cadherin and activation of caspase-3 in human gastric carcinoma AZ-521 cells infected with Mycoplasma hyorhinis. J Vet Med Sci 72, 869-874.

157. Lee JH, Shin JU, Jung I, Lee H, Rah DK, Jung JY, Lee WJ (2013), Proteomic profiling reveals upregulated protein expression of hsp70 in keloids. Biomed Res Int 2013, 621538.

158. Goder M, Kornhaber R, Bordoni D, Winkler E, Haik J, Tessone A (2016), Cutaneous basal cell carcinoma arising within a keloid scar: a case report. Onco Targets Ther 9, 4793-4796.

159. Jia J, Wang M, Song L, Feng Y (2017), A melanotic malignant melanoma presenting as a keloid: a case report. Medicine (Baltimore) 96, e9047.

160. Sleiwah A, Clinton A, Herbert K (2018), Delayed diagnosis of dermal leiomyosarcoma mimicking keloid scar. BMJ Case Rep 2018, pii: bcr-2017-222616.

161. Ueno H, Kanemitsu Y, Sekine S, Ishiguro M, Ito E, Hashiguchi Y, Kondo F, Shimazaki H, Mochizuki S, Kajiwara Y, Shinto E, Yamamoto J (2017), Desmoplastic pattern at the tumor front defines poor-prognosis subtypes of colorectal cancer. Am J Surg Pathol 41, 1506-1512.

162. Lee WJ, Song SY, Roh H, Ahn HM, Na Y, Kim J, Lee JH, Yun CO (2018), Profibrogenic effect of high-mobility group box protein-1 in human dermal fibroblasts and its excess in keloid tissues. Sci Rep 8, 8434 . 
163. Krusius T, Ruoslahti E (1986), Primary structure of an extracellular matrix proteoglycan core protein deduced from cloned cDNA. Proc Natl Acad Sci USA 83, 7683-7687.

164. Mann DM, Yamaguchi Y, Bourdon MA, Ruoslahti E (1990), Analysis of glycosaminoglycan substitution in decorin by site-directed mutagenesis. J Biol Chem 265, $5317-5323$.

165. Winnemöller M, Schmidt G, Kresse H (1991), Influence of decorin on fibroblast adhesion to fibronectin. Eur J Cell Biol 54, 10-17.

166. Dawoody Nejad L, Biglari A, Annese T, Ribatti D (2017), Recombinant fibromodulin and decorin effects on NF- $\mathrm{BB}$ and TGF $\beta 1$ in the $4 \mathrm{~T} 1$ breast cancer cell line. Oncol Lett $13,4475-4480$.

167. Yamaguchi Y, Ruoslahti E (1988), Expression of human proteoglycan in Chinese hamster ovary cells inhibits cell proliferation. Nature 336, 244-246.

168. Yamaguchi Y, Mann DM, Ruoslahti E (1990), Negative regulation of transforming growth factor-beta by the proteoglycan decorin. Nature 346, 281-284.

169. Schönherr E, Broszat M, Brandan E, Bruckner P, Kresse H (1998), Decorin core protein fragment Leu155-Val260 interacts with TGF-beta but does not compete for decorin binding to type I collagen. Arch Biochem Biophys 355, $241-248$
170. Liu Y, Wang X, Wang Z, Ju W, Wang D (2016), Decorin inhibits the proliferation of HepG2 cells by elevating the expression of transforming growth factor- $\beta$ receptor II. Exp Ther Med 12, 2191-2195.

171. Border WA, Okuda S, Languino LR, Ruoslahti E (1990), Transforming growth factor-beta regulates production of proteoglycans by mesangial cells. Kidney Int 37, 689-695.

172. Neill T, Schaefer L, Iozzo RV (2012), Decorin: a guardian from the matrix. Am J Pathol 181, 380-387.

173. Merline R, Moreth K, Beckmann J, Nastase MV, ZengBrouwers J, Tralhão JG, Lemarchand P, Pfeilschifter J, Schaefer RM, Iozzo RV, Schaefer L (2011), Signaling by the matrix proteoglycan decorin controls inflammation and cancer through PDCD4 and MicroRNA-21. Sci Signal 4, ra75.

174. Takeuchi Y, Kodama Y, Matsumoto T (1994), Bone matrix decorin binds transforming growth factor-beta and enhances its bioactivity. J Biol Chem 269, 32634-32638.

175. Goetsch KP, Niesler CU (2016), The extracellular matrix regulates the effect of decorin and transforming growth factor beta-2 (TGF- $\beta 2$ ) on myoblast migration. Biochem Biophys Res Commun 479, 351-357.

176. Ji C, Liu H, Xiang M, Liu J, Yue F, Wang W, Chu X (2015), Deregulation of decorin and FHL1 are associated with esophageal squamous cell carcinoma progression and poor prognosis. Int J Clin Exp Med 8, 20965-20970.

Cite this article as: Brücher BLDM, Jamall IS. (2019), Undervalued ubiquitous proteins. 4open, 2, 7. 